Kevin M. F. Platt

\title{
Eisenstein's Ivan the Terrible, Indeterminacy, and the Hermeneutics of Suspicion
}

Kevin M.F.Platt Professor of Russian and East European Studies, University of Pennsylvania (Philadelphia, USA)
At the outset of my contribution to this forum, I will state without equivocation that I greatly admire this book. I will also state that I am flummoxed by it. To my mind, these responses are indicative of the significance and importance of Joan Neuberger's intervention in Eisenstein scholarship.

First, the praise: This Thing of Darkness is the most complete, well researched and documented, and thoughtful reckoning with Eisenstein's Ivan the Terrible films that we now have. It is encyclopedic in capacity, but also beautifully written and argued. It offers provocative interpretations, a comprehensive account of the history of Eisenstein's project, as well as excellent syntheses of previous writing about the films. All agree that the Ivan the Terrible, Parts I and II, are among the most important films in the Soviet and world canon and are crucial for understanding Eisenstein, himself one of the most important directors of Soviet and world cinema. Undoubtedly, then, the Ivan the Terrible project is worthy of treatment in a separate monograph. I would dare say that it is a mystery why no one has made such an attempt before, although the sheer size of the archive and the complexity of Eisenstein's work suggests that perhaps previous scholars have been simply daunted. This monograph meets those challenges superbly - it is an impressive, milestone accomplishment of careful scholarship. 
I am a cultural historian, a reader of texts and films who seeks to explain their meanings in relation to social contexts and to both their actual or implied historical audiences and later ones, including ourselves, the inheritors of great works of art such as Eisenstein's films ${ }^{1}$. I will focus my contribution around hermeneutics and the approaches of diverse disciplines to the problem of making sense of works of art. As all are aware, there is plenty of room for argument about Eisenstein's Ivan the Terrible. What follows should therefore be taken as the reaction of one scholar who sees things differently than does Neuberger. It should not be taken to diminish my sincere admiration for her accomplishment with this book.

This Thing of Darkness describes Eisenstein's project as an exercise in Aesopian art. In Neuberger's interpretation, the director concealed a subversive message, condemning Ivan the Terrible and by analogy Stalin, beneath an orthodox "surface narrative" that conformed to the official apologetic representation of Ivan, and by analogy Stalin, as heroic figures in service of great historical goals: "Eisenstein constructed a surface narrative that was politically acceptable, with recognizable elements of Socialist Realist narrative, and then proceeded to saturate that narrative with misdirection, contradiction, and a visual style that continually invites the viewer to look beyond appearances" (39). In Neuberger's account, the superficial features of the films correspond to the expectations of the Soviet cultural bureaucracy and reflect the Stalinist rehabilitation of Ivan and his era as predecessors for present-day political actors and scenarios of conflict with external and internal aggressors in the service to the Muscovite state - as "the prototype of the great multinational state of the USSR", in the words of historian Robert lu. Vipper in $1943^{2}$. Yet with the films' other, less explicit features, Eisenstein used every means at his disposal to undermine the Stalinist celebration of Ivan, and by analogy, Stalin.

Neuberger's interpretations compellingly explain Eisenstein's films as introducing doubt at every level concerning the legitimacy of Ivan's actions and service to his ostensible great goals. Consider, for instance, a passage that touches on one of the chief concerns in the history of Ivan the Terrible, from the perspective of Stalinist Russia: his role as the first crowned tsar and great historical actor who centralized Muscovite state power as never before. (NB: I make no claims about whether these conceptions of Ivan corresponded to any historical reality or not). Neuberger cites Eisenstein's diary entry of September 16, 1941, in which he writes:

The theme of one-man rule [edinovlastie] has a two-sided resolution.

One - one-man rule [edinovlastnyi]

Two - alone/lonely [odinokii]

The first gives the theme of state power (progressive at the given historical stage) - the political theme of the film.

The second gives the personal theme - the psychological theme of the film.

In this lies the compositional unity of the personal and the social, the psychological and the polit[ical].

Neuberger's initial commentary on this passage is as follows:

The unity of the personal and political in this comment has often been cited as evidence that the tragic nature of the film resides in Ivan's sacrifice of his wife and friends for the sake of 
national destiny. But while Eisenstein undoubtedly meant for us to see Ivan's lonely sacrifice as the logical - and tragic - outcome of the centralization of power, Eisenstein's portrait goes deeper. He challenges us to consider why Ivan is alone, why everyone betrays him. Are the boyars and clerics in his inner circle simply outwitted by Ivan's superior will and cunning and historical necessity? Or did they have good reasons for opposing Ivan. Did Ivan cause his own loneliness $[\ldots]$ ? Or is he the victim of trauma, of destructive early-modern state-building politics, or even fate? (192)

Up to this point, I am fully in agreement with Neuberger. All of the available evidence, and most importantly the finished films themselves, support the conclusion that they are studies in contradiction ${ }^{3}$. Eisenstein created a compositional unity of opposites that cannot be reduced to simple conclusions in either direction. While orthodox Stalinists might seek to describe the tragedy that afflicted Ivan and all around him and the terror he unleashed as sacrifices that made possible great, super-individual goals, the audience can never cease doubting such an assessment. And neither, by the way, can Ivan.

Yet now consider the conclusion of Neuberger's discussion of this passage a few pages later, that quotes the triumphal, properly Stalinist, opening titles of Part I:

Even as early as Part I, the state is not only not united: it is ripped apart. Its tragedy is not exclusively due to the opposition of the reactionary selfish boyars but also to Ivan's own ruthless pursuit of power and his confrontational methods for dealing with boyar resistance. Ivan the Terrible, Part I, is anything but "the story of a man who... created a unified state... spread military glory... achieved great tasks". By Part III, it is the story of the man who destroyed every living thing in parts of his country, even the birds. But even Part I shows Ivan as a man who decides to trick his people into submission if they would not choose him to rule over them and a man who creates his own army of inhuman sons without mothers or fathers to terrorize his political enemies (194).

Here, Neuberger's interpretation becomes categorical. Note the locution "Ivan the Terrible is anything but" and the confidence of the assertion of what kind of a story "it is". Neuberger achieves a degree of certainty that is extraordinarily difficult to support in relation to these films. In fact, I would suggest that she reaches precisely the degree of certainty that Eisenstein sought to unsettle. The hermeneutic complication is that Neuberger's certainty is diametrically opposed to the Stalinist certainty that was Eisenstein's chief target. Yet the problem remains that these films brook no reductive resolution of their contradictions of any sort. The proper locution is not "anything but", but "both": Ivan was both a glorious state-builder and a bloody tyrant. Eisenstein's demand of viewers, then and now, is to confront historical uncertainty, not to abandon Stalinist certainties in favor of other, anti-Stalinist ones - even if the latter appear more palatable to us today ${ }^{4}$.

Space does not allow presentation here of many other examples like this in detail, but it is fair to say that they make up the entire structure of This Thing of Darkness. Consider, in this regard, a passage from Neuberger's conclusion:

Readings of Ivan the Terrible today continue to be stubbornly ambivalent, apolitical or doubtful about Eisenstein's position on power, so I want to state in the strongest possible terms 


\begin{abstract}
that the evidence I have presented here shows that Eisenstein's work on Ivan the Terrible was radical, critical and subversive. While Eisenstein never saw Ivan as a simple stand-in for Stalin and had much more in mind that the contemporary political themes involved in such a critique, everything that Eisenstein explored in the film [...] contribute[s] to a work of art that uncovers and dissects the monstrous principles and practices of Stalinist socialism. Eisenstein used the institutions of Stalinist artistic production and a Socialist Realist narrative façade not only to expose the cruelties of Stalin and his circle but to challenge every fundamental principle of Soviet socialist ideology (344).
\end{abstract}

Neuberger's confidence in her conclusions is confounding. Throughout This Thing of Darkness, she offers brilliant expositions of Eisenstein's view of human history as an inscrutable dialectical process in which progressive change is always linked to archaic violence. Yet she insistently caps her analyses with categorical, moralistic conclusions that are at odds both with the films themselves and with the evidence she has so painstakingly accumulated: Ivan's "choices [had] tragic consequences for Ivan personally and for the whole country" (105); his "great cause, the Great Russian State, however justified, pales in the light of the scale of its collateral damage" (184); Ivan's "inner conflicts had consequences: real deadly, unambiguous consequences for the people around him" (344). Such formulae fail to capture the complexity of Eisenstein's Ivan the Terrible and its view of history. This is not to say that the films were not subversive in intent and effect. They were intentionally equivocal, which was subversive enough in Stalin's Soviet Union.

My resistance to Neuberger's approach is as much about distinctions among scholarly disciplines as it is about the argument of This Thing of Darkness, proper. For heuristic purposes, we may distinguish between two approaches to the problem of interpretation of cultural life of the past. The first, which might be called a "hermeneutic positivist" stance, seeks categorical conclusions about the meaning of the art object, taking it to be a communicative instrument that expresses a definite message. To this end, the scholar gathers and analyzes all available data relating to its creation and reception - everything that can be recovered relating to the author's documented intent and to the views of contemporaries, as well as those of later scholars, critics, and audiences - adds to this a close analysis of the art work itself, and marshals all into judgements on its "true meaning". This, I would propose, is an apt description of Neuberger's approach. And one must recognize the service This Thing of Darkness carries out for scholarship in gathering and collating an immense trove of material.

Yet the question of conclusions about the "true meaning" of Ivan the Terrible is fraught. Neuberger's approach, in which she sorts evidence into surface narrative and deep, subversive messages, and sorts interpretations of the films into misguided ones that miss the deep structures and a correct one that recovers them, gives great pause. Perhaps it reflects the thinking of a historian, and perhaps my reactions to it reflect the response of a literary and cultural historian. Some years ago, a literary critic would have raised, in connection with the question of Eisenstein's own thinking about his project, the problem of the "intentional fallacy" 5 . Who is to say that the "actual" meaning of an artwork corresponds to the intentions of is creator? Especially, one might add, in the case of a film that was created by a collective of actors, 
cameramen, craftsmen, bureaucrats and cultural-political organizations, rather than an individual? A separate objection to Neuberger's approach might be stated in terms of more recent discussions of the "hermeneutics of suspicion" - critical reassessments of interpretative methods that assume that the meanings that can be derived from a work of art or literature can be divided into illusory "superficial" ones and more authentic "deep ones" - into red herrings and concealed truths ${ }^{6}$. What if the "true" reading is the most obvious one?

Such objections might be moot if we were discussing a work of art about which there was some degree of convergence between the stated intent of its creator, the apparent implications of the work itself, and the reactions of audiences, authoritative interpreters, and later critics and scholars. With Ivan the Terrible, we are nowhere near such a situation. The reactions of contemporaries were multiple and contradictory $^{7}$. The interpretations of subsequent audiences and commentators have been extraordinarily varied ${ }^{8}$. And despite detailed study of Eisenstein's archival legacy, no one (not even Neuberger) has produced a Rosetta Stone that could render Eisenstein's intentions lucid - even if we were inclined to take the director's word as the last one on the matter.

What is the alternative to this problematic approach? It is a mode of interpretation that accepts that Ivan the Terrible is multiplicitous and contradictory - and then folds this insight back into the batter of interpretation. This is the approach of cultural history ${ }^{9}$. What if the reason we have so many conflicting responses to these films is, simply, that they are inherently contradictory? Furthermore, let us note that Ivan the Terrible is itself balanced at the border between history and cultural representation of history and that it offers explicit insight into the problem of interpretation - the interpretation of history. Eisenstein's films articulate meta-positions that allow us to find support for our decisions regarding the proper mode for their interpretation. Should we approach them as empirical historians, or as cultural critics? Well, how did Eisenstein approach the stuff of history in these films?

Eisenstein wrote that history "insistently poses the question of interpretation" (9). This was perhaps one of most subversive things one could say about history in the Stalinist era, which was dedicated to a conception of both historical truth and present experience as knowable in ultimate fashion by means of a correct, party-minded, authoritative analysis. The genius of Eisenstein's films lies in their reintroduction of the problem of unsettled interpretation as central to the question of making sense of both history and lived experience. Ivan the Terrible does not allow Ivan to become a completed and known myth structure, epic in nature, isolated in the past, establishing a reference point against which to read off the true meaning of present events and figures - allowing contemporary audiences to confirm the party line by closing off both history and the present into completed, meaningful, narrative wholes. This was the aim of other comparable historical film projects of the Stalinist era, like Vladimir Petrov's Peter the First, for instance ${ }^{10}$. Instead, Eisenstein presented a vision of the past that was just as infected with uncertainty as is every authentic present. These are films about the undecidability of human history, both in retrospect, and as it is being experienced, about the persistent absence of interpretive certainty, even as it is "insistently posed". 
In reading Neuberger's This Thing of Darkness, one feels the urgency of the author's efforts to prove that Eisenstein offered an unequivocal, "radical" and "subversive" denunciation of Stalin and the social violence of his era - one that accords with our own rejection of the Stalinist legacy. I sympathize with this effort, but it is misguided. Considered in his own social context, one cannot but appreciate Eisenstein's bravery in articulating a different, but no less subversive position: as seen through the lens of Ivan the Terrible, Stalinist Russia was revealed to be incomplete, charged with contradictions that made it impossible to come to conclusions concerning the meaning of events. Would Stalinist violence be justified by later generations as the price history exacted to defend humanity from fascism, or would it be excoriated for its devolution into social violence and inability to achieve the dreams of universal human justice that it ostensibly set out to serve? Such questions were legion, yet suppressed by the social and discursive machinery of the state. An Eisensteinian approach to Eisenstein's final films must recognize that their subversive repudiation of interpretative certainty articulates the only adequate path to their own interpretation ${ }^{11}$. No matter how much we might desire the morally uplifting conclusion that they present an unequivocal denunciation of Stalinism, their meaning lies elsewhere. They demonstrate that the interpretation of history and art is never finished, always contradictory, open to the future. It is a message that is as relevant for our times as it was for Eisenstein's.

1 The work in which I most fully treat the problem of interpretation of Eisenstein's Ivan the Terrible films is: Platt K.M. F. Terror and Greatness: Ivan and Peter as Russian Myths (Ithaca, 2011). In addition, see: Platt K. M. F., Brandenberger D. "Terribly Romantic, Terribly Progressive or Terribly Tragic? Rehabilitating Ivan IV Under I. V. Stalin, 1937-1953”, Russian Review, vol. 58, no. 4, 1999, pp.635-654; Brandenberger D., Platt K. "Terribly Pragmatic: Rewriting the History of Ivan IV's Reign"? Epic Revisionism: Russian History and Literature as Stalinist Propaganda, eds Kevin M. F. Platt, David Brandenberger (Madison, 2006), pp. 157-178.

2 Vipper R.Yu. Transcript of the public lecture by Acad. Vipper R. Yu., given on 17 Sep 1943 in the Column Hall of the House of Unions in Moscow (Moscow, 1943), pp. 8-9.

3 By available evidence, I mean Eisenstein's production notes and drawings, his memoirs and theoretical writings, his public pronouncements concerning the project in the Soviet press, as well as the archival record of his statements in the production and oversight process for the films, but perhaps most importantly the evidence provided by the films themselves.

4 Authoritative examples of scholarly work that understands Eisenstein as a covert antiStalinist and the second part of his Ivan the Terrible as an expression of dissent include the writings of Naum Kleiman and, more forcefully, Leonid Kozlov. See Kleiman's notes to S. M. Eisenstein "Izbrannye proizvedeniia": Eisenstein S.M. Selected works, in 6 vols (Moscow, 1964-1971), vol.6, pp.548-551; Kozlov L. "The Artist and the Shadow of Ivan", Stalinism and Soviet Cinema, eds Derek Springm, Richard Taylor (London, 1993), pp. 109-130. Other late Soviet and early post-Soviet authors have often followed these examples, perhaps in an attempt to "save" Eisenstein from the taint of Stalinism at a moment when critique of the Soviet past in toto had become the norm both in scholarship and in the politics of history more generally.

5 The fundamental critical work on the "intentional fallacy" is: Wimsatt W. K., Beardsley M. C. The Verbal Icon: Studies in the Meaning of Poetry (Lexington, 1954); see also: Rabinowitz P. J. "The Intention Debates", A Companion to Literary Theory, ed. by David H.Richter (Hoboken, 2018), pp. 85-99.

6 See, for instance: Felski R. "Suspicious Minds", Poetics Today, vol.32, no.2, 2011, pp. 215-234. 
7 See: Neuberger J. This Thing of Darkness: Eisenstein's Ivan the Terrible in Stalin's Russia (Ithaca, 2019), pp. 306-321.

8 See n. 4 above for examples of scholars who are, like Neuberger, inclined to view Eisenstein as a "closet dissident". As a contrasting example, one might adduce for a start Aleksandr Solzhenitsyn, who channeled an opposed view through a character in his One Day in the Life of Ivan Denisovich who, in the course of a discussion of the Ivan the Terrible films, states: "The political motive behind them is utterly loathsome - an attempt to justify autocratic tyranny. [...] Don't call [Eisenstein] a genius - call him a toady, a dog carrying out his master's orders. A genius doesn't adjust his treatment of a theme to a tyrant's taste". Solzhenitsyn A. One Day in the Life of Ivan Denisovich: A Novel, transl. by H.T. Willetts (New York, 2005), p. 97 (translation adjusted for accuracy). A more recent, and to my mind, well balanced account is that of Katerina Clark, who discusses Eisenstein's placement of Ivan in a broader, European Renaissance context: "Arguably, Eisenstein produced in this film an allegorical representation of national glory by locating that 'terrible' phase of Russian history within a pan-European context that included the Renaissance as a time of extraordinary cultural achievement. From this perspective, though the film is patriotic and inflected by a purge mentality, it could be read as presenting the life of Ivan as the tragedy of an able leader: in a sort of Faustian bargain, he implements the violence that might facilitate a national flowering, but in its misdirected excess that flowering eludes him”. See: Clark K. Moscow, the Fourth Rome: Stalinism, Cosmopolitanism, and the Evolution of Soviet Culture, 1931-1941 (Cambridge, 2011), p. 3.

9 For a robust theorization of such a model of interpretation as applied to cultural objects, see: Fish S. Is There a Text in This Class: The Authority of Interpretive Communities (Cambridge, 1980). For work applying comparable hermeneutic principles to more properly historical problems, see Reinhart Koselleck's many essays in conceptual history, including those recently collected in: Koselleck R. Sediments of Time: On Possible Histories, ed. and transl. by Sean Franzel, StefanLudwig Hoffmann (Stanford, 2018).

10 For Eisenstein's dismissive comments on Petrov's film, see: Tsivian Y. Ivan the Terrible (London, 2002), p. 36.

11 This is my own approach to interpretation of the films — see: Platt, Terror and Greatness, pp. 232-252.

\title{
FOR CITATION
}

Platt K. M. F. 'Eisenstein's Ivan the Terrible, Indeterminacy, and the Hermeneutics of Suspicion', Modern History of Russia, vol. 11, no. 1, 2021, pp. 240-247. https://doi.org/10.21638/11701/spbu24.2021.118 UDC 94(47).084

\begin{abstract}
This essay praises Joan Neuberger's book This Thing of Darkness (Cornell University Press, 2019) as a great accomplishment in cinematic interpretation and a detailed and subtle historical account. It contests Neuberger's argument that Eisenstein's Ivan the Terrible films present an unequivocal critique of Stalin and Stalinism by means of a historical analogy with Ivan. Platt argues that the films are intentionally, stubbornly ambivalent in their representation of Ivan, and by extension Stalin. He contends that although this was indeed a subversive movie in the Stalinist USSR, Eisenstein's films did not offer any finalized conception of the historical role of these figures, and instead should be viewed as works that thematize the impossibility of achieving certainty in historical interpretation. In reading Neuberger's This Thing of Darkness, one feels the urgency of the author's efforts to prove that Eisenstein offered an unequivocal, "radical" and "subversive" denunciation of Stalin and the social violence of his era - one that accords with our own rejection of the Stalinist legacy. Author sympathizes with this effort, but it is misguided. Considered in his own social context, one cannot but appreciate Eisenstein's bravery in articulating a different, but no less subversive position: as seen through the lens of Ivan the Terrible, Stalinist Russia was revealed to be incomplete, charged with contradictions that made it impossible to come to conclusions concerning the meaning of events.
\end{abstract}

Keywords: Eisenstein, Ivan the Terrible, Stalin, cinema, hermeneutics, suspicion. 
Author: Kevin M. F. Platt - Professor of Russian and East European Studies, University of Pennsylvania (Philadelphia, USA); kmfplatt@sas.upenn.edu

University of Pennsylvania, 1, College Hall, Philadelphia, PA 19104, USA

References:

Brandenberger D., Platt K. 'Terribly Pragmatic: Rewriting the History of Ivan IV's Reign', Epic Revisionism: Russian History and Literature as Stalinist Propaganda, eds Kevin M. F. Platt, David Brandenberger (Madison, 2006).

Clark K. Moscow, the Fourth Rome: Stalinism, Cosmopolitanism, and the Evolution of Soviet Culture, 1931 1941 (Cambridge, 2011).

Eisenstein S. M. Selected works: in 6 vols (Moscow, 1964-1971). (In Russian)

Felski R. 'Suspicious Minds', Poetics Today, vol. 32, no. 2, 2011.

Fish S. Is There a Text in This Class: The Authority of Interpretive Communities (Cambridge, 1980).

Koselleck R. Sediments of Time: On Possible Histories, ed. and transl. by Sean Franzel, Stefan-Ludwig Hoffmann (Stanford, 2018).

Kozlov L. 'The Artist and the Shadow of Ivan', Stalinism and Soviet Cinema, eds Derek Spring, Richard Taylor (London, 1993).

Neuberger J. This Thing of Darkness: Eisenstein's Ivan the Terrible in Stalin's Russia (Ithaca, 2019).

Platt K. M. F. Terror and Greatness: Ivan and Peter as Russian Myths (Ithaca, 2011).

Platt K. M. F., Brandenberger D. 'Terribly Romantic, Terribly Progressive or Terribly Tragic? Rehabilitating Ivan IV Under I. V. Stalin, 1937-1953', Russian Review, vol. 58, no. 4, 1999.

Rabinowitz P. J. 'The Intention Debates', A Companion to Literary Theory, ed. by David H. Richter (Hoboken, 2018).

Solzhenitsyn A. One Day in the Life of Ivan Denisovich: A Novel, transl. by H. T. Willetts (New York, 2005).

Tsivian Y. Ivan the Terrible (London, 2002).

Vipper R. Yu. Transcript of the public lecture by Acad. Vipper R. Yu., given on 17 Sep 1943 in the Column Hall of the House of Unions in Moscow (Moscow, 1943). (In Russian)

Wimsatt W. K., Beardsley M. C. The Verbal Icon: Studies in the Meaning of Poetry (Lexington, 1954).

Received: June 18, 2020

Accepted: October 27, 2020 